\title{
Evaluating the toxicity potential of some insecticides against sugarcane black bug, Cavelerius excavatus (Hemiptera: Lygaeidae)
}

\author{
Ilyas Raza ${ }^{1}$, Muhammad Nasir ${ }^{1 *}$, Muhammad Salman ${ }^{1}$, Muhammad \\ Usman Asif ${ }^{2}$ and Qurat ul Ain Haneef ${ }^{1}$ \\ 1. Pest Warning and Quality Control of Pesticides, Punjab Agriculture Department, Lahore-Pakistan \\ 2. Plant Protection Division, Nuclear Institute of Agriculture, Tandojam-Pakistan \\ *Corresponding author's email: nasirmalik540@gmail.com
}

Citation

Ilyas Raza, Muhammad Nasir, Muhammad Salman, Muhammad Usman Asif and Qurat ul Ain Haneef. Evaluating the toxicity potential of some insecticides against sugarcane black bug, Cavelerius excavatus (Hemiptera: Lygaeidae). Pure and Applied Biology. Vol. 9, Issue 3, pp1701-1707. http://dx.doi.org/10.19045/bspab.2020.90180

\begin{tabular}{llll}
\hline Received: 09/01/2020 & Revised: 22/03/2020 & Accepted: 02/04/2020 & Online First: 08/04/2020
\end{tabular}

\section{Abstract}

A study was conducted on the toxicity potential of six insecticides (Lesenta 80\% WG, Trunk 20\% SC, Karate 2.5 EC, Route 57 EC, Refree 5\% SC and Thimet 5G) against the sugarcane black bug (C. excavatus) at two different locations in tehsil Kot Addu District Muzaffargarh, Pakistan. Seven treatments including control with three replications were maintained following Randomized Complete Block Design (RCBD). The treatments were applied at their recommended doses and mortality data were recorded before and after 24 followed by 48, 72 and 168 hours of application. The results revealed that all the insecticides significantly suppressed the target pest population compared to control. Route $57 \mathrm{EC}$ (Malathion) was revealed as most effective insecticide due to causing highest mortality in both locations $84.29 \%$ and $84.44 \%$ followed by Trunk $20 \%$ SC (Clothinadion) with $80.03 \%$ and $79.88 \%$ mortality of the target pest after 168 hours of application. Whereas Karate 2.5 EC (Lambda cyhalothrin) was evaluated as least effective with 51.95\% and $52.97 \%$ mortality at both locations, respectively. Our results suggest that Route 57 EC (Malathion) @ $500 \mathrm{ml}$ per acre is effective against sugarcane black bug and can be used for the chemical management of this pest.

Keyword: Black bug; Efficacy; Insecticides; Malathion; Sugarcane

\section{Introduction}

Agriculture is the backbone of country and has main role in poverty reduction by providing $38.5 \%$ employment and sharing 18.5\% to Gross Domestic Product [1]. Sugarcane is one of the important cash crop of Pakistan. It is cultivated on an area of 1.1 million hectares with total production of 62.8 million tones by contributing $0.6 \%$ to GDP and $3.1 \%$ to agriculture's value addition [2, $3]$. There is lot of constraints between the potential yield and the average yield ( $47 \mathrm{tha}$ $\left.{ }^{1}\right)$ that the farmers are obtaining in Pakistan [4]. In terms of sugarcane production and area the country occupies fifth and sixth position respectively [5]. 
Like cotton crop the farmers of this crop are also facing lot of problems, both yield and area are declining due to many factors such as water shortage, less economic returns, higher cost of production and low sugar recovery. Among these reasons the main problem for low yield is insect pest infestation on this crop [6]. Worldwide the crop is attacked by more than 1500 species of insect pests [7] and about 48 species of insects pests are reported from Indo-Pakistan [8] while some important insect pests have been documented from Pakistan [9] as well as from Sindh [10]. Important insect pest attacking the crops are the borers, bugs and leafhoppers.

Black bug (Cavelerius excavatus) (Dist.) is a widely distributed pest and suck cell sap by residing in the whorl of sugarcane crop [11]. Recently, it has become a serious pest of sugarcane in some areas in Pakistan such as Kot Bhahi Khan Sugarcane Farm, Yousaf Sugar Mill Shahpur Sargodha. Both adults and Nymphs cause damage by sucking cell sap from the plants. The leaves of the affected plants turn yellow with brown patches. The growth of the plant and quality of the juice is adversely affected [12]. Adults and nymphs of $C$. excavatus sucks the cell sap gregariously from the young plants [11]. The adult black bugs move freely and in this way infestation progressed from one plant to other while young ones are less mobile. In case of heavy attack the plant desiccate and even death of plant can occur. The growth of plant is severely affected by feeding of 4-6 bugs/plant for 4-6 days [13]. As this pest attain the status of regular pest and its occurrence gaining attention from sugarcane farmers for its exclusion. Farmers mostly rely on the use of synthetic chemicals for its management. Keeping in view, the present study was conducted to evaluate the toxicity potential of different insecticides against $C$. excavatus under the agro-climatic conditions of tehsil Kot Addu District Muzaffargarh, Pakistan.

\section{Materials and methods}

The trials were conducted simultaneously at the farmer's fields located in two sugar mills areas i.e. Fatima Sugar Mill and Shiekhu Sugar Mill of tehsil Kot Addu District Muzaffargarh during the year 2017. The sugarcane variety HSF 240 was sown during September, 2016. The experiment was laid out under RCBD with seven treatments along with three replications. Total six insecticides were evaluated for their efficacy against black bug (Table 1).

Table 1. Details of insecticides used in the experiment

\begin{tabular}{|c|c|c|c|}
\hline Treatments & Trade name & Common name & Recommended dose/ acre \\
\hline T1 & Lesenta $80 \% \mathrm{WG}$ & Imidacloprid+Fipronil & $45 \mathrm{gm}$ \\
\hline T2 & Trunk 20\%SC & Clothinadion & $100 \mathrm{ml}$ \\
\hline T3 & Karate 2.5EC & Lambda cyhalothrin & $330 \mathrm{ml}$ \\
\hline T4 & Route 57EC & Malathion & $500 \mathrm{ml}$ \\
\hline T5 & Refree 5\% SC & Fipronil & $480 \mathrm{ml}$ \\
\hline T6 & Thimet 5G & Phorate & $10 \mathrm{~kg}$ \\
\hline T7 & Control & & \\
\hline
\end{tabular}

These insecticides were obtained from local pesticide market and applied at their recommended doses by using knap sack sprayer. An area of $41 \mathrm{~m}$ x $40.5 \mathrm{~m}$ (1 kanal) was devoted to each treatment replication. The insecticides were applied at both locations when $C$. excavatus population reached at economic threshold level (10/sheath). In control plot no spray was applied. All agricultural practices like hoeing, irrigation and fertilizer application was kept uniform throughout the experiment 
in all treatments. The data of black bug population were recorded before 24 hours and after 24, 48, 72, 168 hours of application. For data recording, 25 plants from each replication were selected randomly by taking five plants from each of the four corners and fifth from the middle of the plot. Selected plants outer leaves were removed and black bug in the leaf sheath were collected on the white paper sheet and then counted. Percentage reduction in $C$. excavatus population was calculated through Abbot's formula;

$$
\text { Percentage population reduction }=\frac{A-B}{A} \times 100
$$

Where $\mathrm{A}=$ Pre-treatment black bug population, $\mathrm{B}=$ Post treatment black bug population.

The data was analyzed by using statistical software Statistix 8.1. Black bug mean population data from different plots were analyzed by using analysis of variance (ANOVA) to compare the effectiveness of different insecticides. Differences in means were calculated by least significant difference test.

\section{Results and discussion}

The mean populations of black bug in different treatments before 24 hours and after 24, 48, 72 and 168 hours of spray at Fatima and Shiekhu Sugar Mills are shown in (Table 2 \& 3), respectively. The insecticidal treatments were found significantly different from each other. Percentage reductions in population after insecticidal application at Fatima and Shiekhu Sugar Mill are shown in (Fig. 1 \& 2), respectively. Highest black bug population reduction (29.9\%) after 24 hours of spray in Fatima sugar mill plots was seen in plots treated with Route (Malathion) with 10.40 black bug/ sheath followed by Trunk (Clothinadion) with 16.1 Black bugs/sheath and percent reduction of $27.9 \%$. Similarly, in Shiekhu sugar mill plots treated with Route and Trunk shown maximum percent reduction of $19.4 \%$ and $16.50 \%$ in population of Black bug with 14.50 black bugs/sheath and 18.4 black bugs/sheath, respectively. The least effective insecticide after 24 hours of applications at Fatima Sugar Mill was Karate (Lambda cyhalothrin) with $12.9 \%$ reduction
(14.1 black bug/sheath) followed by Thimet (Phorate) with $18.5 \%$ reduction (10.2 black bug/sheath), respectively. While in Shiekhu Sugar Mill, Lesenta (Imidacloprid+Fipronil) and Karate (Lambda cyhalothrin) were least effective by decreasing population to 15.76 and 14.6 black bug/sheath with percent reduction of $7.4 \%$ and $10.2 \%$, respectively. After 48 hours of spray at Fatima sugar mill black bug population in Route (Malathion), Trunk (Clothinadion) and Refree (Fipronil) treated plots were $6.76,10.3$ and 10.6 black bug/sheath with percent reduction of $54.4 \%$, $53.9 \%$ and $38.8 \%$, respectively. While Trunk (Clothinadion) and Refree (Fipronil) treated plots were statistically non-significantly different from each other. Black bug population in Thimet treated plots was 7.1/sheath (43.28\% reduction) and was found better than Refree (Fipronil) as compared to 24 hours. Least effective insecticide was Karate (Lambda cyhalothrin) that decreases population to only $15.61 \%$. In Shiekhu sugar mill black bug population per sheath after 48 hours of spray in Route (Malathion), Trunk (Clothinadion), Refree (Fipronil) and Lesenta (Imidacloprid+Fipronil) treated plots were 10.56, 14.43, 13.46 and 12.96 black bug/sheath with percent reduction of $41.30 \%, 34.49 \%, 27.86 \%$ and $23.87 \%$, respectively, Refree (Fipronil) and Trunk (Clothinadion) treated plots were found nonsignificantly different from each other. Among all the tested insecticides, Karate was recorded the least effective in controlling black bug population with $22.09 \%$ reduction. 
After 72 hours of spray at Fatima Sugar Mill, black bug population in Route (Malathion) and Trunk (Clothinadion) treated plots were 5.06 and 8.1 black bug/ sheath with $65.89 \%$ and $63.73 \%$ percent reduction while 6.20 (65.56\%) and 10 (54.61\%) in Shiekhu sugar mill plots, respectively. All these insecticidal treated plots were statistically significantly different from each other. Refree (Fipronil) and Phorate (Thimet) also showed promising results at Fatima Sugar Mill by reducing black bug population to $56.73 \%$ and $58.46 \%$, respectively. Insecticidal efficacy of Trunk (Clothinadion) was better after 3rd day of spray by decreasing pest population with percent reduction of $63.73 \%$ and $54.61 \%$ at Fatima and Shiekhu Sugar mills, respectively as compared to 24 hours of spray.

Further decrease in population of black bug was observed with increase in time at both locations. After 168 hours of spray, Route (Malathion) gave maximum reduction of $84.29 \%$ and $54.44 \%$ followed by Trunk (Clothinadion) and Refree (Fipronil) whereas Karate (Lambda cyhalothrin) was least effective with minimum percent reduction of $51.95 \%$ and $52.97 \%$ at Fatima and Shiekhu sugar mills, respectively.

The present findings showed that Route (Malathion) followed by Trunk (Clothinadion) performed best among the different insecticides against black bug population. As the work on black bug population was little and lack of sufficient reviews only few previous studies reported the comparative effectiveness of different insecticides against this pest. These results are partially in line with the findings of Trdan et al. [14] who reported that Malathion was the most effective at reducing the damage on white cabbage plants caused by cabbage stink bugs. Jaipal [15] reported that insecticide application of Endosulfan (Thiodan, 35\%EC) at $500 \mathrm{ml}$ a.i. ha ${ }^{-1}$. was more effective in reducing infestation followed by treatments where trash was burnt or removed. Tewari and Yadav [16] determined efficacy of various insecticides (Viraat, Marshal, Acephate, Endosulfan, Acetamiprid, Carina, Polytrin and Karate) in controlling black bug and mealy bug infesting sugarcane. All the tested insecticides provided efficient control of the pest compared to the control, with acephate and acetamiprid treatment resulting in the highest mortality of the black bug (93.33 and 98.33\%) and mealy bug (95.00 and $96.66 \%$ ) in 1999-2000 and 2000-01, respectively. Zada et al. [12] conducted experiment on sugarcane black bug and observed that average infestation of the black bug were $43.81 \%, 75.17 \%$ and $64.06 \%$ in biological, chemical and untreated plots. Shivashankara [17] showed that soil application of pre-mix insecticide imidacloprid+acephate @3000 g/ha was most effective followed by its next doses @ $2500 \mathrm{~g} / \mathrm{ha}$ and @ $2000 \mathrm{~g} / \mathrm{ha}$ in reduction of black bug population during both the seasons. Pandey et al. [18] conducted experiment to find out the efficacy of new insecticides i.e. Triazophos and Profenophos+Cyper with two standards Chlorpyriphos and Quinolphos. The result revealed that the application of Profenophos 40\%+Cyper 4\% @ $1000 \mathrm{ml} /$ ha causes $54.38 \%$ mortality at 48 hr $79.04 \%$ at $72 \mathrm{hr}$ and $91.90 \%$ at 7 days intervals followed by $53.38 \%, 71.90 \%$ and $88.61 \%$ at $48 \mathrm{hr}, 72 \mathrm{hr}$ and at 7 days intervals respectively with application of Preofenophos 40\% + Cyper 4\% @ 750 ml/ha. 
Table 2. Mean numbers of black bug/sheath before 24 hours and after 24, 48, 72 and 168 hours of spray at Fatima Sugar Mill area farmer field

\begin{tabular}{|c|c|c|c|c|c|c|}
\hline \multirow{2}{*}{ Treatments } & \multirow{2}{*}{ Insecticide Name } & \multicolumn{5}{|c|}{ Black bug population / sheath (Mean \pm S.E) } \\
\cline { 3 - 7 } & & Pre-Treatment & \multicolumn{4}{|c|}{ Post Treatment } \\
\cline { 3 - 7 } & & Before 24 Hours & After 24 Hours & After 48 hours & After 72 hours & After 168 hours \\
\hline $\mathbf{T}_{\mathbf{1}}$ & Lesenta 80\%WG & $14.33 \pm 1.27 \mathrm{~cd}$ & $11.3 \pm 0.17 \mathrm{de}$ & $9.1 \pm 0.23 \mathrm{~cd}$ & $7.2 \pm 0.33 \mathrm{c}$ & $5.8 \pm 0.87 \mathrm{bc}$ \\
\hline $\mathbf{T}_{\mathbf{2}}$ & Trunk 20\%SC & $22.33 \pm 0.66 \mathrm{a}$ & $16.1 \pm 1.03 \mathrm{ab}$ & $10.3 \pm 0.36 \mathrm{c}$ & $8.1 \pm 0.15 \mathrm{bc}$ & $4.46 \pm 0.41 \mathrm{~cd}$ \\
\hline $\mathbf{T}_{\mathbf{3}}$ & Karate 2.5EC & $16.23 \pm 0.44 \mathrm{bc}$ & $14.1 \pm 0.46 \mathrm{bc}$ & $13.70 \pm 0.85 \mathrm{~b}$ & $9.20 \pm 0.49 \mathrm{~b}$ & $7.80 \pm 0.45 \mathrm{~b}$ \\
\hline $\mathbf{T}_{\mathbf{4}}$ & Route 57EC & $14.83 \pm 0.55 \mathrm{bcd}$ & $10.4 \pm 0.3 \mathrm{e}$ & $6.76 \pm 0.29 \mathrm{~d}$ & $5.06 \pm 0.08 \mathrm{~d}$ & $2.33 \pm 0.12 \mathrm{~d}$ \\
\hline $\mathbf{T}_{\mathbf{5}}$ & Refree 5\% SC & $17.33 \pm 0.48 \mathrm{~b}$ & $13.2 \pm 0.17 \mathrm{~cd}$ & $10.6 \pm 0.33 \mathrm{c}$ & $7.5 \pm 0.40 \mathrm{bc}$ & $5.2 \pm 0.11 \mathrm{c}$ \\
\hline $\mathbf{T}_{\mathbf{6}}$ & Thimet 5G & $12.51 \pm 1.26 \mathrm{~d}$ & $10.2 \pm 0.58 \mathrm{e}$ & $7.1 \pm 0.20 \mathrm{~d}$ & $5.20 \pm 0.11 \mathrm{~d}$ & $4 \pm 0.52 \mathrm{~cd}$ \\
\hline $\mathbf{T}_{\mathbf{7}}$ & Control & $15.20 \pm 0.7 \mathrm{bc}$ & $17.43 \pm 1.01 \mathrm{a}$ & $21.66 \pm 2.02 \mathrm{a}$ & $27 \pm 1.73 \mathrm{a}$ & $29.33 \pm 1.76 \mathrm{a}$ \\
\hline \multicolumn{2}{|c|}{$\mathbf{F}(\mathbf{D F}=\mathbf{3 , 6})$} & $13.33^{*}$ & $19.07 *$ & $33.39^{*}$ & $145.48^{*}$ & $140.97 *$ \\
\hline
\end{tabular}

Means in a column sharing same letter are not significantly different at $\mathrm{p}<0.05$

Table 3. Mean numbers of black bug/sheath before 24 hours and after 24, 48, 72 and 168 hours of spray at at Shiekhu Sugar Mill area farmer field

\begin{tabular}{|c|c|c|c|c|c|c|}
\hline \multirow{3}{*}{ Treatments } & \multirow{3}{*}{$\begin{array}{l}\text { Insecticide } \\
\text { Name }\end{array}$} & \multicolumn{5}{|c|}{ Black Bug population/sheath $($ Mean \pm S.E $)$} \\
\hline & & \multirow{2}{*}{$\begin{array}{l}\text { Pre-Treatment } \\
\text { Before } 24 \text { Hours }\end{array}$} & \multicolumn{4}{|c|}{ Post treatment } \\
\hline & & & After 24 Hours & After 48 hours & After 72 hours & After 168 hours \\
\hline $\mathbf{T}_{1}$ & Lesenta $80 \% \mathrm{WG}$ & $17.03 \pm 0.84 b$ & $15.77 \pm 0.43 b c$ & $12.96 \pm 0.12 b c$ & $10.00 \pm 0.57 b c$ & $7.00 \pm 0.72 b c$ \\
\hline$\overline{\mathbf{T}_{2}}$ & Trunk 20\%SC & $22.03 \pm 0.47 \mathrm{a}$ & $18.40 \pm 0.80 \mathrm{a}$ & $14.43 \pm 0.39 \mathrm{~b}$ & $10.00 \pm 1.52 b c$ & $4.43 \pm 0.33 \mathrm{~d}$ \\
\hline $\mathbf{T}_{3}$ & Karate 2.5EC & $16.3 \pm 1.25 \mathrm{~b}$ & $14.63 \pm 0.31 \mathrm{c}$ & $12.70 \pm 0.35 b c$ & $10.90 \pm 0.49 \mathrm{~b}$ & $7.66 \pm 0.42 b$ \\
\hline$\overline{T_{4}}$ & Route 57EC & $18.00 \pm 0.85 b$ & $14.50 \pm 0.87 \mathrm{c}$ & $10.56 \pm 0.90 \mathrm{c}$ & $6.20 \pm 0.56 c$ & $2.80 \pm 0.11 \mathrm{~d}$ \\
\hline $\mathbf{T}_{5}$ & Refree $5 \%$ SC & $18.66 \pm 0.75 b$ & $16.60 \pm 1.30 \mathrm{abc}$ & $13.46 \pm 0.86 \mathrm{~b}$ & $9.26 \pm 1.36 \mathrm{bc}$ & $5.10 \pm 1.05 \mathrm{~cd}$ \\
\hline$T_{6}$ & Thimet 5G & $16.03 \pm 0.52 b$ & $14.13 \pm 0.76 c$ & $12.10 \pm 1.70 \mathrm{bc}$ & $9.46 \pm 0.31 b c$ & $4.96 \pm 1.15 \mathrm{~cd}$ \\
\hline $\mathbf{T}_{7}$ & Control & $16.83 \pm 1.67 \mathrm{~b}$ & $18.17 \pm 0.08 \mathrm{ab}$ & $20.40 \pm 0.81 \mathrm{a}$ & $25 \pm 0.57 \mathrm{a}$ & $31.60 \pm 0.94 \mathrm{a}$ \\
\hline \multicolumn{2}{|c|}{$F(D F=3,6)$} & $4.88 *$ & $4.33 *$ & $11.64 *$ & $24.18^{*}$ & $159.89 *$ \\
\hline \multicolumn{2}{|c|}{ P Value } & 0.0096 & 0.0148 & 0.0002 & 0 & 0 \\
\hline \multicolumn{2}{|c|}{ LSD } & 2.88 & 2.59 & 2.84 & 3.83 & 2.45 \\
\hline
\end{tabular}

Means in a column sharing same letter are not significantly different at $\mathrm{p}<0.05$ 


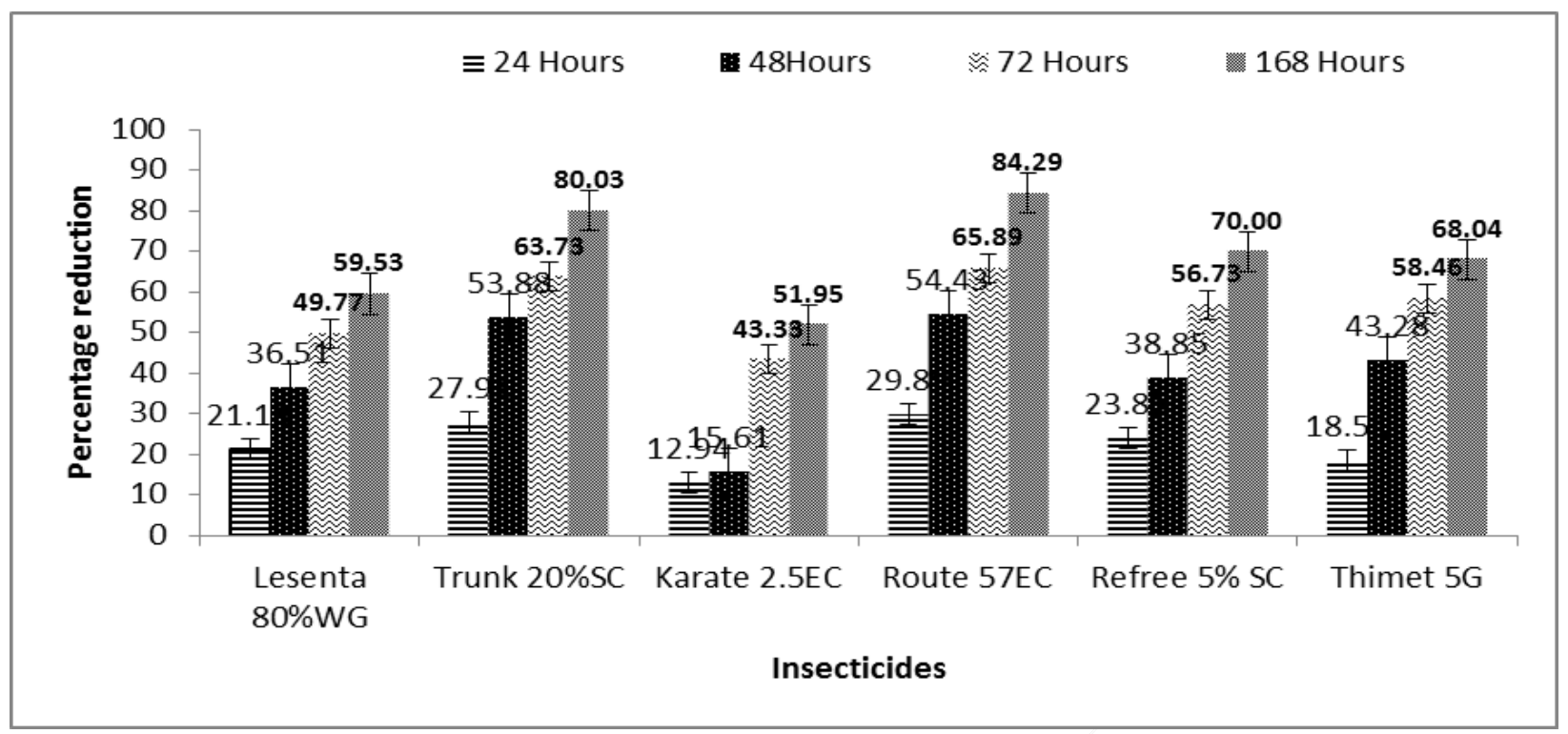

Figure 1. Percentage reduction of Black Bug population after 24, 48, 72 and 168 hours of spray at Fatima Sugar Mill area farmer field

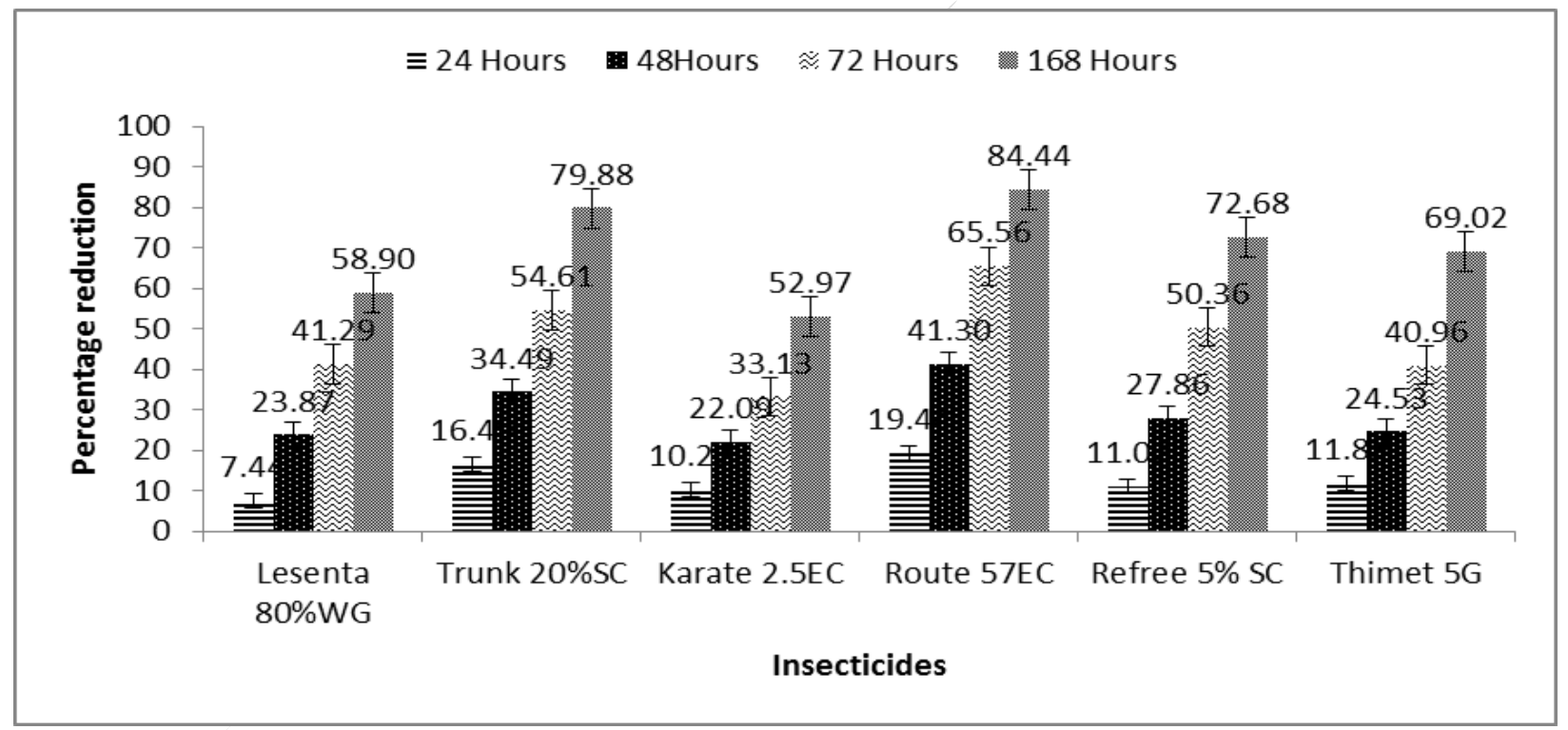

Figure 2. Percentage reduction of black bug population after 24, 48, 72 and 168 hours of spray at Shiekhu Sugar Mill area farmer field

\section{Conclusion}

From present study it is concluded that Sugarcane black bug population in insecticidal treated plot is significantly reduced compared to control plot. However the insecticides Malathion (Route 57 EC) and Clothinadion (Trunk $20 \% \mathrm{SC}$ ) proved more promising and can be recommended to sugarcane growers for the control of Sugarcane black bug by Agriculture extension workers.

Authors' contributions

Conceived and designed the experiments: I Raza, Performed the experiments: M Nasir \& 
M Salman, Analyzed the data: QA Haneef, Contributed materials/ analysis/ tools: I Raza \& M Salman, Wrote the paper: MU Asif, M Nasir \& QA Haneef

\section{References}

1. GOP (2019). Pakistan Economic Survey, 2018-19. Ministry of Finance, Government of Pakistan, pp 11.

2. FAOSTAT (2014). Production of crops: Sugarcane. Retrieved November 10, 2015, from http://faostat3.fao.org/browse/ $\mathrm{Q} / \mathrm{QC} / \mathrm{E}$

3. FAOSTAT (2015). Production of crops: Sugarcane. Retrieved November 10, 2015, from http://faostat3.fao.org/ browse/Q/QC/E

4. Zafar M., Umar M, Chatha AA, Grawal MA \& Ahmed F (2003). Comparative performance of elite sugarcane clones and advance nursery stage for growth, quality and disease response. Pak Sugar J 18: 8-12.

5. Azam M \& Khan M (2010). Significance of the sugarcane crops with special reference to NWFP. Sarhad J Agric 26(2): 289-295.

6. Ullah F, Shakur M, Badshah H, Ahmad S, Amin M \& Zamin M (2012). Efficacy of Trichogramma chilonis Ishii in comparison with two commonly used insecticides against sugarcane stem borer, Chilo infuscatellus Snellen (Lepidoptera: Pyralidae). J Anim Pl Sci 22(2): 463-466.

7. Box HE (1953). List of sugar-cane insects: a synonymic catalogue of sugar-cane insects and mites of the world, and their insect parasites and predators, arranged systematically London: Commonwealth Institute of Entomology.

8. Rehman KA (1942). Parasites of Insect Pests of Sugar Cane in the Punjab. Ind J Agric Sci 2(1): 119-128.

9. Chaudhry NA \&Ansari MA (1988). Insect pests of sugar cane in Pakistan. Progressive Farming 8(4): 10-18.

10. Naqvi KM (1975). Important insect pests of sugar cane crop in Sindh. Sugar cane crop seminar. Representation and Recommendations, Ciba Geigy, pp 67-70.

11. Atwal AS \& Dhaliwal GS (2009). Agricultural pests of South East Asia and their management. College of agriculture; Ludhiana, India. Kalyani Publishers, New Delhi. 502 pp.

12. Zada. H, Ahmad B, Badshah. H, Saljoqi AUR, Naeem M, Anwar S \& Zamin M (2013). A study of comparison of field effectiveness of coccinillid predators and chemical insecticides in the management of sugarcane black bug Cavelarius excavatus (Dist.) (Lygaedae: Hemiptera) in Shahpur Sargodha, Pakistan. Sarhad J Agric 29(2): 213-217.

13. Morrill WL, Shepard BM, Rida GS \& Parducho M (1995). Damage by the Malayan black bug (Heteroptera: Pentatomidae) in rice. $J$ Econ Entomol 88: 1466-1468.

14. Trdan S, Znidarcic D \& Valic N (2006). Field efficacy of three insecticides against cabbage stink bugs (Heteroptera: Pentatomidae) on two cultivars of white cabbage. Int J Pest Manage 52(02): 79-87.

15. Jaipal S, (1996). Evaluation of mechanical and chemical methods for control of black bug (Ca velerius sweeti) in sugarcane ratoon crop. Ann Appl Biol 128(Suppl): 4-5.

16. Tewari RK, Yadav RA (2005) Bio-efficacy of newer insecticides against black bug (Cavelerius sweeti) and mealy bug (Saccharicoccus sacchari) of sugarcane. Indian J Entomol 67(2): 175-177

17. Shivashankara (2018). Studies on efficacy of pre-mix insecticide combination on major insect pests and natural enemies in sugarcane ecosystem. PhD Thesis, G.B. Pant University of Agriculture and Technology, Pantnagar - 263145 (Uttarakhand). pp 184.

18. Pandey KP, Singh AK, Kureel N, Panday M \& Singh M (2018). Efficacy of new insecticides against black bug (Cavelarius sweeti Slat) of sugarcane. Pestol 42(11): 3335. 